\title{
Zola's Repetitions: On Repetition in Zola
}

\begin{abstract}
Repetition is one of the most striking features of Émile Zola's prose style. It is was also one of the most frequently commented-upon, and frequently criticized, aspects of his writing among contemporaneous critics. This article reads critical responses to Zola's repetitions, as well as Zola's own comments on matters of style, for what they can reveal about the assumptions at work in fin-de-siècle literary criticism's conception of literary craft. It suggests that the hostility displayed towards Zola's repetitions reveals them to have been a vital technique in the novelist's pursuit of a truly popular, democratic novelistic form.
\end{abstract}

Keywords: Émile Zola; fin-de-siècle literary criticism; literary craft; repetition; style 


\section{Zola's Repetitions: On Repetition in Zola}

Do all great novelists have style? Does any? If the example of nineteenth-century France's preeminent prose stylist is anything to go by, to 'have' style is only ever really to worry about it, to worry away at it, to work at it. 'Tu me dis que le style t'emmerde,' Gustave Flaubert wrote to Louis Bouilhet in September 1855. 'Pas plus que moi, je t'assure.' ${ }^{1}$ The remarks on style in Flaubert's correspondence famously consist less in confident pronouncements about 'proper' style, and more in a self-torturing litany of his own shortcomings, a protracted lament of the impossibility of attaining a stylistic perfection that hovers just out of view. Flaubert's dismayed critique of his own style has paradoxically solidified into one of the most enduring images of a 'great stylist' composing: style, it is commonly supposed, is work, more laborious when done properly than perhaps any other aspect of literary composition. The pursuit of style is an endless process of scrutiny at the level of page, paragraph, sentence, word, syllable. That process is, in principle at least, endless.

Few would ever associate this Sisyphean image of Flaubert's stylistic labour with the work of his younger confrere, Émile Zola. To be sure, we might hear in Zola's famous maxim nulla dies sine linea an imprecation to the procrastinating self, rather than the boast of one to whom the next line comes as naturally as morning follows night. Much important recent work in Zola studies has moreover focused on the workmanlike elaboration of the novels, from notes and sketches, through the ébauches and plans, to fair drafts and corrected proofs. ${ }^{2}$ It seems obvious that some of this labour must have been stylistic - and indeed, John C. Lapp and Henri Mitterand both showed some time ago that Zola made extensive stylistic adjustments to his manuscripts, to proofs, and to the feuilleton texts in preparing for book publication. ${ }^{3}$ Yet while the flourishing of genetic criticism on Zola has certainly revealed a great craftsman, the craft he practises strikes us as predominantly a structural one, based on symbolic design, narrative arc, and the harmonious distribution of narrative material, rather than the pointillist pursuit of le mot juste. Few readers would cite Zola as a past master in the craft of style. This may in fact be Zola's paradoxical triumph, since, as Robert Lethbridge points out in introducing what

\footnotetext{
1 Gustave Flaubert, letter to Louis Bouilhet, 13 September 1855 . https://flaubert.univrouen.fr/jet/public/correspondance/trans.php?corpus=correspondance\&id=10120\&th=82. Accessed 24 January 2020.

${ }^{2}$ This type of approach was launched by the conference 'Zola, genèse de l'œuvre' in 1999, and is especially associated with the work of Alain Pagès and Olivier Lumbroso, and the site ArchiZ. See for instance Genesis, 42 (2016), 'L'Écriture du cycle', ed. by Alain Pagès and Olivier Lumbroso.

${ }^{3}$ See John C. Lapp, 'On Zola's Habits of Revision', Modern Language Notes, 73 (1958), 603-11; and Henri Mitterand, 'Remarques d'introduction à l'étude des techniques de la composition et du style chez Émile Zola', Les Cahiers naturalistes, 24 (1963), 79-82.
} 
remains the most important work in English on the novelist's compositional practice, part of the aim of Zola's 'repeated revisions of his prose' was to make that prose seem, precisely, 'artless', unmarked and unmannered, in keeping with his cherished ideal of linguistic transparency. ${ }^{4}$ Yet, today as much as during Zola's own life time, this desired effect of artlessness is all too often taken for an actual absence of art; any critic who wishes to consider Zola's style must first contend with the fact that that style is widely regarded not simply as blank, but as bad.

I raise these questions because in this article, I consider an aspect of Zola's writing that not only seems best understood as a stylistic feature, but is also commonly reputed to be an inadequacy of style: repetition. Zola's extensive use of repetition is perhaps the most striking feature of his prose, or rather, the feature that seems most peculiar to Zola in comparison to his contemporaries. It was also one of the most frequently commented-upon, and criticized, aspects of his work, and in this article I engage quite extensively with negative judgements of Zola's style, in an effort to understand what was at stake in literary-historical terms in the hostile reactions it provoked. Zola himself, moreover, occasionally acknowledged this feature of his writing, and explained it in different ways throughout his career; similarly, critics since his death have often remarked on the place of repetition in the novels, and have offered a variety of accounts of its motivations and its effects. I draw on and amalgamate many of these accounts here, in an attempt to offer an in-the-round view of repetition in Zola. My purpose, however, will not be to 'rehabilitate' Zola's style, still less to 'defend' his use of repetition, for to attempt either of these would already be to acquiesce in a belletristic evaluative logic that forecloses some of the most interesting questions raised by Zola's repetitions. Indeed, in this article I will not cite Zola's fiction very much at all, but will focus instead on a corpus of mostly journalistic writing, including Zola's own. In doing so, I use the phenomenon of repetition in Zola, and others' responses to that phenomenon, as a means of plotting Zola's position in relation to some of the literary tensions and quarrels of his age. These as we shall see include the very nature of literary composition and what truly counts as artistic 'work'; the purpose of the literary text, whether conceived as pedagogical, entertaining, or as something else entirely; the proper concerns of literary criticism; and the relationship between style and form, on the one hand, and modes of dissemination (especially mass dissemination) on the other. Repetition, I hope to show, can give us a new perspective on Zola's unique positioning in literary history as, in

\footnotetext{
${ }^{4}$ Robert Lethbridge, 'Introduction', in Zola and the Craft of Fiction: Essays in Honour of F. W. J. Hemmings, ed. by Robert Lethbridge and Terry Keefe (Leicester: Leicester University Press, 1990), pp. 1-14 (pp. 6, 2).
} 
Fredric Jameson's words, 'the last coexistence of the art novel and the best-seller within a single text' - for it is at the very heart of the novelist's vision of a truly democratic art. ${ }^{5}$

\section{Zola's 'Key-Passages'}

Zola's use of repetition has been a topic of discussion in Zola studies for some time. As early as 1952, Calvin S. Brown offered a taxonomy of Zola's repetitive techniques that includes 'the tag', 'the hammer', 'the slogan', and so on; fifty years later, Béatrice Laville proposed five types of repetition, including litanies and rappels, that she argues characterize the author's later works in particular. ${ }^{6}$ Rather than reproduce these typologies here, I propose for brevity's sake to allude to their various elements as they become relevant. Different repetitive techniques in Zola serve different purposes; there would be much to be said, for instance, about the repetitive syntactic pattern that is a constant feature of Zola's characterizations, as identified by Anatole France in his review of La Terre (1887):

M. Zola fatigue par l'accablante monotonie de ses formules: 'Sa chair tendre de colosse — son agilité de brune maigre—sa gaité de grasse commère—la nudité de son corps de fille solide. ${ }^{7}$

Phrases of this sort constitute one of the most consistent and unmistakeable features of Zola's narrative voice throughout his career, from Thérèse Raquin to Vérité. They are related to what Brown calls 'the tag': 'a word or phrase [...] serving to describe or characterize a person or thing, or to represent a characteristic trait or habit' ${ }^{8}$

In this article, however, I limit myself to the altogether more audacious form of repetition that Brown calls the 'key-passage'. This is 'a relatively long repetition embodying, in a striking and memorable form, one of the fundamental ideas of the book', in which 'repetition is inclined to be exact', and which is obtained, Brown plausibly suggests, by Zola's own turning back to earlier chapters to ensure a close-to-verbatim reprise. ${ }^{9}$ An individual keypassage recurs less often than a tag (three times is the norm), but the extent and exactitude of the repeated matter arguably make them seem much more frequent. I shall offer only one example for now, from La Bête humaine (1890), itself one of a number of candidates in that

\footnotetext{
${ }^{5}$ Fredric Jameson, Postmodernism, or, the Cultural Logic of Late Capitalism (Durham, NC: Duke University Press, 1991), p. 63.

${ }^{6}$ Calvin S. Brown, Repetition in Zola's Novels (Athens: University of Georgia Press, 1952), ch. 2, 5, 9; Béatrice Laville, 'Les Évangiles, entre épuisement et modernité', in Lire / dé-lire Zola, ed. by Jean-Pierre Leduc-Adine and Henri Mitterand (Paris: Nouveau Monde, 2004), pp. 313-26 (p. 323).

${ }^{7}$ Anatole France, 'La Terre', Le Temps, 28 August 1887, p. 2.

${ }^{8}$ Brown, Repetition, p. 5.

${ }^{9}$ Brown, Repetition, p. 23.
} 
novel. In chapter 2, we are introduced to Jacques Lantier and his troubled psychological antecedents. In the company of women, we learn, Jacques invariably feels seized by a desire to avenge some forgotten ancestral slight:

Chaque fois, c'était comme [...] une soif toujours renaissante de venger des offenses très anciennes, dont il aurait perdu l'exacte mémoire. Cela venait-il donc de si loin, du mal que les femmes avaient fait à sa race, de la rancune amassée de mâle en mâle, depuis la première tromperie au fond des cavernes ${ }^{10}$

By chapter 6, things are going better for Jacques; his relationship with Séverine Roubaud seems to have calmed his homicidal urges:

Il ne sentait plus sa soif de venger des offenses très anciennes dont il aurait perdu l'exacte mémoire, cette rancune amassée de mâle en mâle, depuis la première tromperie au fond des cavernes. (RM IV: 1152)

But of course, this cannot last. As Jacques seizes Séverine in chapter 11 and turns upon her the knife with which he was supposed to kill her husband, someone is heard to wonder:

Était-ce sa soif qui était revenue, de venger des offenses très anciennes, dont il aurait perdu l'exacte mémoire, cette rancune amassée de mâle en mâle, depuis la première tromperie au fond des cavernes? (RM IV: 1297)

These key-passages are reasonably straightforward to explain from a narratological point of view: they are essentially a form of foreshadowing, and work by strikingly enacting the necessity and inevitability of the plot's ultimate unfolding. In this example, indeed, the narratological effect is almost to reverse the logical priority of initial statement and subsequent repetition: by a sort of Zolian Nachträglichkeit, the final occurrence is the 'true' one, the first two merely premonitions. Thus in La Bête humaine, that novel of compulsive behaviour, displaced re-enactments of imagined primal crimes, and the rhythmic return and return of the Paris-Le Havre Express, stylistic repetition not only intensifies but mirrors the novel's thematic preoccupations; as Lethbridge points out, the novel's machines and its mécanicien protagonist 'dramatiz[e]' the novelist's own 'technical mastery'. ${ }^{11}$

I have begun with examples of 'key-passages' from this particular novel, then, in order to show Zola's use of repetition at its most richly meaningful. And yet I suspect that even these examples will raise a smirk with some readers, and that many more will consider them, for want of a more precise expression, a bit much. Repetition in fictional prose is often viewed

\footnotetext{
${ }^{10}$ Émile Zola, La Bête humaine, in Les Rougon-Macquart, ed. by Henri Mitterand, 5 vols (Paris: Gallimard, 196067), IV (1966), 1044. References to Les Rougon-Macquart are to this edition and are given in the text.

${ }^{11}$ Robert Lethbridge, 'Zola and the Limits of Craft', in Zola and the Craft of Fiction, pp. 133 - 49 (pp. 134-5).
} 
with suspicion or derision, and this was already the case at the time Zola was writing. Anatole France's complaint that 'M. Zola fatigue par l'accablante monotonie de ses formules' is symptomatic of a primary axis of contemporaneous critiques of Zola's art. Zola's use of repetition, Béatrice Laville notes, 'a été au centre des invectives adressées à ses dernières œuvres. N'a-t-on pas assez dit qu'il pratiquait la redite, le radotage, la répétition, la reformulation, le ressassement?' 12 There is no doubt that repetition occupies an even larger stylistic place in the post-Rougon-Macquart novels, and that readers who found those later novels not to their taste often observed as much. Thus Léon Bloy, in a section of his $\mathrm{Je}$ m'accuse that takes the form of a reading journal of Zola's Lourdes (1894), objects that the same idea may be found 'identiquement exprimée,_-jusqu'à cinq fois, pages 34, 273, 274, 319, et 597. ${ }^{13}$ Nevertheless, and as Laville herself notes, neither the technique nor the hostile response it often provoked was a new phenomenon in the later works. Both were well established by the second half of the Rougon-Macquart cycle.

It is beyond the scope of this article to trace a history of the 'anti-repetitive prejudice' in fictional prose. But the prejudice, we might suppose, is intimately related to the long process - still ongoing in the 1860s, as Pierre Bourdieu has shown - whereby the novel established itself as an autonomous form with its own aesthetic codes. ${ }^{14}$ This process involved a stylistic differentiation of artistic prose from poetry, among the primary manifestations of which was the refusal of the repetition that is so congenial to poetic language: repetition of words (anaphora), of whole syntagms and lines (the 'refrain'), and of course most obviously of individual phonemes in rhyme. By about 1880, all of those forms of repetition had come to be viewed as infelicitous in fictional prose, which was now to be characterized above all by its unpoetic and in a sense unrhetorical character. And there is little doubt as to who was the leading recent exponent of this stylistic prescription: it was of course Gustave Flaubert, whose manuscripts show an almost obsessive aversion to repetition — of words, of course, but also of sounds and parts of words, often pages apart. That aversion had already become legendary by the time of Flaubert's death in 1880. It is indeed the ghost of Flaubert that Bloy calls upon in deploring, at another moment of Je m'accuse, Zola's repetitions: what would hardworking Flaubert say, Bloy asks, if he were to be confronted with the endless repetitions of Lourdes or La Bête humaine? ${ }^{15}$ Of course, this rapprochement as Bloy offers it here is rigged against Zola.

\footnotetext{
${ }^{12}$ Laville, 'Les Évangiles', p. 319.

${ }^{13}$ Léon Bloy, Je m'accuse (Paris: La Maison d'Art, 1900), p. 38.

${ }^{14}$ Pierre Bourdieu, Les Règles de l'art: genèse et structure du champ littéraire (Paris: Seuil, 1998 [1992]), p. $151-55$.

${ }^{15}$ Bloy, Je m'accuse, p. 21.
} 
Yet I think the Zola-Flaubert comparison, when viewed through the lens of repetition, can reveal rather more about nineteenth-century literary thinking than one might expect of so seemingly banal a pairing. In pursuing it now, I shall focus less on Flaubert's and Zola's styles, and more on their stylistic reputations.

\section{'Our finally fatal sense of the procédé'}

'Sa conscience du style est moins aiguë, surtout moins maladive, que celle de Flaubert,' writes Henri Mitterand of Zola; 'mais elle est réelle.' ${ }^{16}$ Indeed, it should be reiterated that Zola was, broadly speaking, entirely in solidarity with Flaubert's de-prettifying, de-poeticizing stylistic impulse; 'selon lui', notes Philippe Hamon, 'la langue doit être "transparente", [...] pour rendre compte du réel, sans ce que l'on pourrait appeler un "embu" stylistique, sans effet de littérarité' ${ }^{17}$ This attitude is summed up, as many critics have noted, in the eminently Flaubertian aspiration expressed in the Ébauche of La Bête humaine, that the novel should be composed 'sans art visible'. ${ }^{18}$ Zola was moreover evidently aware that repetition in fiction was a risky strategy, even sharing some version of his contemporaries' presumption that it was usually bad. Olivier Lumbroso highlights 'les connotations régulièrement péjoratives des verbes "répéter" et "reproduire" et du substantif "répétition" dans les dossiers préparatoires'. And finally, he was most certainly aware of Flaubert's dim view of stylistic repetition. Indeed, we owe one of the most striking evocations of the older novelist's ruthless editorial process to Zola himself. In December 1880, seven months after Flaubert's death, Le Figaro's literary supplement carried an article by Zola entitled 'Mes souvenirs sur Gustave Flaubert'. In it, Zola hailed the late writer as the proverbial novelist's novelist, the originator of a mode of truthful and observational writing that Zola labels 'la formule'-I shall say more about this word shortly_ 'que nous, ses cadets, avons prise dans Madame Bovary'. Zola then proceeds to discuss Flaubert's compositional practice, including the celebrated gueuloir method of autodeclamation, before ending with some considerations on what he calls 'le tourment de plus en plus aigu de la seule perfection du style'. ${ }^{19}$ In the portrait that follows, the anti-repetitive prejudice occupies a privileged place:

\footnotetext{
${ }^{16}$ Henri Mitterand, 'Remarques d'introduction à l'étude des techniques de la composition et du style chez Émile Zola', Les Cahiers naturalistes, 24 (1963), 79-82 (p. 80).

${ }_{17}$ Philippe Hamon, 'Échos et reflets: l'ébauche de La Bête humaine de Zola', Poétique, 109 (1997), 3-16 (p. 5).

${ }^{18}$ Ébauche to La Bête humaine, $\mathrm{f}^{\mathrm{o}}$ 338/1, transcribed by Geoff Woollen, in Zola, 'La Bête humaine': colloque du centenaire à Glasgow, ed. by Geoff Woollen (Glasgow: University of Glasgow French and German Publications, 1990), pp. $28-62$ (p. 28).

${ }^{19}$ Émile Zola, 'Mes souvenirs sur Gustave Flaubert', Le Figaro: supplément littéraire, 11 December 1880, p. 198.
} 
Éviter les répétitions, les rimes [...] n'était encore que le gros de la besogne. Il en arrivait à ne pas vouloir que les mêmes syllabes se rencontrassent dans une phrase [....].

Je ne puis même donner ici une idée de ses scrupules en matière de style. [....] Un dimanche, nous le trouvâmes somnolent, brisé de fatigue. La veille, dans l'aprèsmidi, il avait terminé une page de Bouvard et Pécuchet, dont il se sentait très content, et il était allé dîner en ville [...]. Lorsqu'il rentra vers minuit, au lieu de se coucher tout de suite, il voulut se donner le plaisir de relire sa page. Mais il resta tout émotionné, une répétition lui avait échappé, à deux lignes de distance. Bien qu'il n’y eût pas de feu dans son cabinet, et qu'il fît très froid, il s'acharna à ôter cette répétition.

Zola concludes that 'ce désir de la perfection a été, chez le romancier, une véritable maladie qui l'épuisait et l'immobilisait.' 20

These recollections comport with the established stylistic reputation of the writer of Madame Bovary; note the close resemblance between the language used by Zola here, and Henri Mitterand's opposition between the two writers cited earlier (where Flaubert's stylistic hypersensitivity is 'aiguë' and 'maladive'). ${ }^{21}$ Clearly, this depiction of Flaubert is tailored to suit Zola's own strategic purposes, and there is more going on here than a mere disagreement about taste, still less about healthy working practices. In reality, nothing less than the vocation of fiction is at issue. Flaubert's 'véritable maladie' is a literary one, whose progression, Zola tells us, may be traced across Flaubert's career: 'Qu'on le suive attentivement [...] depuis Madame Bovary jusqu'à Bouvard et Pécuchet: on le verra peu à peu s'absorber dans la forme [...], se donner de plus en plus au procédé. ${ }^{22}$ Flaubert's hatred of repetition, down to the chance echoes of the arbitrary signifier, is evidence for Zola of a fetishization of language that is unbecoming of a prose writer. This allows us to nuance a claim I made earlier: for if the autonomization of the novel involved a differentiation of novelistic from poetic language at the level of specific stylistic features, it was also the process by which the novel conquered the same aesthetic status as poetry, and whereby the novelist's labour could lay claim to the same degree of aesthetic refinement as the poet's. Flaubert's style and the elaborate process whereby it was achieved embody this degree of stylization, while Zola's style — and this by his own lights, if only implicitly—refuses it. ${ }^{23}$ Instead, Zola anticipates Jean-Paul Sartre's famous

\footnotetext{
${ }^{20}$ Zola, 'Mes souvenirs', p. 199.

${ }^{21}$ Mitterand, 'Remarques d'introduction', p. 80.

${ }^{22}$ Zola, 'Mes souvenirs', p. 199.

${ }^{23}$ See Bourdieu, Les Règles de l'art, p. 166-67, on Flaubert's reputation as a 'poetic' formalist.
} 
insistence that prose, in contradistinction to poetry, is duty-bound to be straightforwardly communicative and referential, and that prose style 'doit passer inaperçu' ${ }^{24}$

One senses a false dichotomy here, and my interest is less in settling the dispute than in interrogating the metaphors and vocabulary in which it is couched. Consider for instance Zola's apparently non-pejorative reference to a 'formule' for the novel that younger novelists had supposedly found in Madame Bovary; and his subsequent, definitely pejorative, image of a Flaubert abandoning himself 'au procédé'. Both of these words are more storied than they may appear. As Lumbroso points out, they belong to the special jargon of a late nineteenth-century literary criticism that had evolved to be 'moins moraliste et plus formaliste', and therefore required 'une nouvelle thématique des jugements esthétiques, celle d'une écriture d'artifices conventionnels'. ${ }^{25}$ Such words are thus artefacts of a double literary history: on the one hand, the history of the autonomization of the novel to which I have already alluded, whereby that genre established itself as a self-regulating domain with its own technique; on the other, the wider liberation of literature and literary criticism from evaluative principles rooted in moral example or social utility (in other words, the emergence of Bourdieu's autonomous champ littéraire). To live up to this double autonomy, it seems, the nineteenth-century novelist must have a formule, must learn the appropriate procédés. But — and here's the rub - the novelist's art, for Zola as much as for the authors of the many examples cited by Lumbroso, is an invisible art, an art sans art visible; if the reader spots the procédé, then art becomes mere artifice. Put differently, procédé and formule are necessarily ambivalent terms, for to identify one at work is tantamount to saying that it does not, in fact, work.

With that in mind, let us consider some more examples, the first of which we have already encountered-Anatole France on La Terre, in 1887:

M. Zola fatigue par l'accablante monotonie de ses formules : 'Sa chair tendre de colosse [etc]'.26

Jules Lemaître, in a sympathetic review of La Bête humaine, from 1890:

La Bête humaine est un des romans [...] où apparaît le plus crûment l'artifice de quelques-uns de ses procédés de composition. On dirait que lui-même les a appliqués ici un peu mécaniquement et avec une sorte d'ennui. ${ }^{27}$

France again, this time in a broadly positive review of L'Argent, in 1891:

\footnotetext{
${ }^{24}$ See Jean-Paul Sartre, Qu'est-ce que la litterature? (Paris: Gallimard, 1948), pp. 25-32 (p. 30).

${ }^{25}$ Olivier Lumbroso, Zola autodidacte: genèse des ouvres et apprentissages de l'écrivain en régime naturaliste (Paris: Droz, 2013), p. 255.

${ }^{26}$ France, 'La Terre', p. 2.

27 Jules Lemaître, 'La Bête humaine', Le Figaro, 8 March 1890, p. 1.
} 
Sans doute, on y sent le procédé. On y retrouve les longues énumérations auxquelles M. Zola nous a habitués et les retours réguliers des mêmes formes de langage [...]. Le style, de plus en plus simple, est épaissi et négligé. Mais une puissance extraordinaire anime cette lourde machine. ${ }^{28}$

The full version of the earlier citation from Léon Bloy, conveying his disgusted response to Lourdes (1894), published in 1900:

Que ne dirait-il [Flaubert] pas, [...] en lisant aujourd'hui Lourdes ou La Bête humaine? en voyant reparaître, toutes les vingt pages, les isochrones formules de ce balancier inconscient qu'on nomme l'auteur? ${ }^{29}$

And finally, Henry James's rueful evaluation of Zola's later works, in an article published shortly after the novelist's 'premature and disastrous death', in 1903:

Rome, as the second volume of The Three Cities, appeared [...] the mere triumph of a mechanical art, a 'receipt' applied with the skill of long practice. [In Vérité] there are passages [...] of the old full-bodied sort, [whose] misfortune is to have been discounted by our intensified, our finally fatal sense of the procédé. ${ }^{30}$

One could find many more examples. What strikes one first in these instances is an implicit ideology of work. Claire White, following some remarks of Roland Barthes, notes that 'in the aftermath of 1848 , the writer was forced to renegotiate his engagement with society; and this manifested itself [...] in the writer's self-immolatory impulse to assume the role of a literary labourer.' ${ }^{31}$ As we have seen, no figure embodied this new writerly self-justification better than Flaubert. What emerges from these critiques of Zola's writing is a stylistic reputation that is in this regard the opposite of Flaubert's: while Flaubert works himself half to death in pursuit of style, notably via the elimination of all suspicion of repetition, Zola simply isn't working hard enough, relying instead on the repetition of the same old tricks. Certainly, this is Bloy's point in invoking Flaubert and his 'labeur infini', which puts to shame the younger confrere whose voluminous back catalogue has been obtained through the lazy recycling of "trente ou quarante [...] inusables clichés'. 'Il est vraiment difficile de se tuer moins que ce grand travailleur,' Bloy concludes with his habitual sarcasm. ${ }^{32}$

\footnotetext{
${ }^{28}$ Anatole France, 'L'Argent, par M. Émile Zola', Le Temps, 22 March 1891, p. 2; the first sentence is among the examples highlighted by Lumbroso.

${ }^{29}$ Bloy, Je m'accuse, p. 21.

${ }^{30}$ Henry James, 'Émile Zola' (1903), in Literary Criticism: French Writers (New York: Library of America, 1984), pp. 871—99 (pp. 872, 887, 896).

${ }^{31}$ Claire White, Work and Leisure in Nineteenth-Century French Literature and Visual Culture: Time, Politics and Class (Basingstoke: Palgrave Macmillan, 2014), p. 35.

${ }^{32}$ Bloy, Je m'accuse, pp. 19, 20.
} 
Yet these quotations contain some additional tensions. When, for instance, France describes the style of L'Argent as 'négligé', one might suppose that he is drawing attention to an absence of style: a writing that is unselfconscious and unpolished, spontaneous yet artlesssomething like the stylistic reputation of Balzac, perhaps. Yet the charge that 'on y sent le procédé' surely suggests something different—a self-consciousness, if a misdirected one, that leaves the work conspicuously mannered. If Zola and Flaubert are stylistic opposites, then, they oppose each other in a sort of paradoxical chiasmus of effort invested and result obtained: on the one hand, Flaubert wastes hours in stylistic labour whose purpose is precisely to leave no trace, resulting in a blank prose purged even of accidental features that might be mistaken for crass procédés; on the other, Zola expends minimal effort on style, and thus accidentally produces writing in which stylistic procédés are groaningly obvious. I say 'accidentally', because it is another tension within these critiques of Zola's style that so seemingly deliberate a device as his use of repetition should nevertheless be depicted as somehow not deliberate, but rather as occurring despite himself. Bloy is the most explicit about this: his opposition is not simply between laborious Flaubert and lazy Zola, but between a Flaubert who, though no genius, was 'un volontaire' following a consciously devised aesthetic plan, and Zola whose formules are the work of a mere 'balancier inconscient' ${ }^{33}$ I have discussed elsewhere how Zola was and continues to be subjected to a 'herméneutique du malgré-lui', whereby the features fair and foul of his work are invariably presented as unconscious and unintentional; for the authors of the 1887 'Manifeste des Cinq', and subsequently for Max Nordau, we recall, Zola wrote under the sway of a compulsive coprolalia, for instance. ${ }^{34}$ This approach might seem paradoxical when it is applied to the use of stylistic devices, as it is by Bloy here: surely artifice cannot be 'inconscient'? Yet if we consider Bloy's epithet in full—'balancier inconscient' we can see that something similar is at play in the France, Lemaitre, and James examples as well, in their allusions to the mechanical quality of Zola's writing. Lethbridge as we have seen maintains that the machine and the mécanicien at the heart of La Bête humaine 'dramatiz[e]' Zola's own 'technical mastery'. ${ }^{35}$ Indeed - but they also dramatize the ambivalence of that very metaphor, whose double-edgedness these critical quotations reveal. A machine is a work of artifice and craft, but it can only do what it is designed to do, and with ever decreasing efficiency; the mechanic is skilled, to be sure, but his skills consist in a set of repeated gestures

\footnotetext{
${ }^{33}$ Bloy, Je m'accuse, p. 20.

${ }^{34}$ Andrew J. Counter, 'Le Symptôme Zola: fragment d'autoanalyse critique', Les Cahiers Naturalistes, 91 (2017), $61-71$.

${ }^{35}$ Lethbridge, 'Zola and the Limits of Craft', pp. 134-5.
} 
that may not even be conscious in the execution. It would appear that nineteenth-century thinking allowed the same to be true of prose style: once acquired, the 'craft' of the autonomous novelist can become a compulsion like any other behaviour. This is, indeed, exactly what Zola is saying about Flaubert - in whose stylistic labours, which Bloy presents as pure efforts of will, Zola diagnoses a 'véritable maladie'.

In highlighting these paradoxes, my purpose is not to defend Zola's use of repetition, but to give a sense of the intellectual poverty of fin-de-siècle (and conceivably all) stylistic criticism, by which I mean, evaluative stylistic criticism, as applied to prose. Lumbroso is right to note the Third-Republic evolution of critical writing about the novel, away from the censorious moralism that was so resurgent under the Second Empire, towards an evaluative discourse of style, technique and form. Yet one might also see in fin-de-siècle critical formalism the evidence of an incomplete evolution, wherein the pedantry and normative assumptions of the pre-1870 regime set up a rump government in the domain of style. In any case, it seems as if, when criticism finally stopped throwing veils over nudes, it was the critic himself who turned out to be naked, clutching only a set of a priori concepts and Platonic ideals that no real prose writer could conceivably make manifest, and returning-repetitively, inevitably - the same sort of judgements. A version of this point was made by Guy de Maupassant in 'Le Roman' (1888):

Je ne suis pas le seul à qui le même reproche soit adressé par les mêmes critiques, chaque fois que paraît un livre nouveau.

$[\ldots$.

— Le plus grand défaut de cette œuvre c'est qu'elle n'est pas un roman à proprement parler.

On pourrait répondre par le même argument:

— Le plus grand défaut de l'écrivain qui me fait l'honneur de me juger, c'est qu'il n'est pas un critique. ${ }^{36}$

A true critic, Maupassant continues, should write 'sans parti pris, sans opinions préconçues', and should not really judge at all; rather, 'il faut [qu'il] comprenne, distingue et explique toutes les tendances les plus opposées, [...] et admette les recherches d'art les plus diverses'. In truth, critics such as France and Lemaître often rose to this challeng, just as Zola could succumb to the same evaluative traps when discussing Flaubert's 'improper' stylistic habits. My point,

\footnotetext{
${ }^{36}$ Guy de Maupassant, 'Le Roman', in Romans, ed. by Louis Forestier (Paris; Gallimard, 1987), pp. 703-15 (p. 703).
} 
really, is not that the critics were wrong, but that the stylistic or formalist criterion they worked with, what we might call their critical procédé, was itself an unhelpful straitjacket. In the remainder of this article, then, I want to move beyond the purely stylistic, to consider Zola's repetitions as, in Maupassant's phrase, a recherche d'art.

\section{Repetition as leitmotif}

Even if we can agree with Zola that Flaubert's urge to flush out all repetition had something demented about it, this observation falls well below a positive justification of repetition as a technique. Zola only began to offer anything like the latter in the mid-1890s, meaning: after the conclusion of the Rougon-Macquart series; in the midst of what we might call the literary 'market correction' announced in Jules Huret's 1891 Enquête sur l'évolution littéraire, wherein the dominance of the Naturalist-realist formule was challenged on various sides; and at the very moment when, as Laville points out, Zola's use of repetition was about to escalate significantly. ${ }^{37}$ In analysing that development in Zola's later output, Laville echoes Maupassant in insisting that 'l'axe qui nous intéresse ici n'est pas celui de la valeur, [...] mais celui du travail de l'auteur en tant qu'il prend en compte la quête d'une autre forme romanesque'. ${ }^{38} \mathrm{We}$ might add to this that the 1890s was the moment that Zola himself came to feel able to speak about his style in a more speculative way-but that he consistently did so not only prospectively, but also retrospectively, reinterpreting his oeuvre to date in line with his new thinking. In these comments, Zola supplies two ways of understanding his use of repetition, which, while not necessarily antagonistic, are not obviously compatible either. The two explanations proposed by Zola are what we might call the 'musical' and the 'pedagogical' hypotheses. In this section, I consider the first of these.

Here is Zola, interviewed in Le Journal on 20 August 1894:

[Mes livres] sont des monuments: en un mot, ils sont 'composés'. Mais ce n'est pas dans une vue de beauté. Il ne s'agit pour moi que de faire vivant, et je sais bien que la vie recèle toujours un mystère. J'ai procédé comme Wagner, sans beaucoup le connaître, au début, et je pense que, comme lui, c'est le sentiment de la vie qui m'a conduit à ce procédé. J'utilise aussi les harmonies obtenues par le retour des phrases, et n'est-ce pas le meilleur moyen de donner un son à la signification muette des choses $?^{39}$

\footnotetext{
${ }^{37}$ Laville, 'Les Évangiles', p. 319. See Jules Huret, Enquête sur l'évolution littéraire, ed. by Daniel Grojnowski (Vanves: Thot, 1982).

${ }^{38}$ Laville, 'Les Évangiles', p. 313.

${ }^{39}$ Émile Zola, Écrits sur le roman, ed. by Henri Mitterand (Paris: Le Livre de Poche, 2004), p. 315.
} 
In this interview, Zola assimilates an idea about his work that has already been circulating for a while. In his scrupulously mixed 1890 review of La Bête humaine, Paul Ginisty (editor of La Vie populaire, which had carried the novel in feuilleton) had noted that 'le passage des trains furieux revient, en effet, sans cesse développé, comme le leitmotivé [sic] dans une œuvre wagnérienne'; while France's review of L'Argent the following year alludes to the idea in evoking 'les retours réguliers des mêmes formes de langage qu'on a comparées aux phrasesthèmes de Wagner'. ${ }^{40}$ In 1894, following the Le Journal interview, Zola's sometime close associate Henry Céard chimed in with an article in Le Matin, apparently prompted by the rumour that Zola was to write an operatic libretto (presumably the drame-lyrique Messidor, with music by Alfred Bruneau, staged in 1897). We ought not to be surprised at this turn of events, Céard explains, because 'les procédés par lui employés dans l'exécution de ses livres sont des procédés empruntés à l'art musical'. He continues:

M. Zola, par un artifice semblable aux artifices du contre-point et de la fugue, ramène avec un parti pris savant et obstiné les termes exprimant l'idée dominante de son livre. Qu'on ne croie pas [...] à des néglicences et à des répétitions amenées par la fatigue.

Point du tout. Ce sont là des effets voulus et calculés qui sont appliqués systématiquement, à peu près comme Richard Wagner [...] fait réapparaître [...] les dessins mélodiques [...]. Comme l'auteur de la Tétalogie [sic], l'auteur des Rougon se sert de thèmes conducteurs et pourrait montrer ses leit-motiv. ${ }^{41}$

These quotations inaugurate a thread of Zola criticism that continues to the present day; a number of Zola critics have commented on the 'symphonic' or 'musical' aspects of the novelist's work. ${ }^{42}$ Such intermedial comparisons, though often very enabling, are always at bottom metaphorical, and what these moments from the 1890s usefully suggest is that it is very specifically the repetitive character of Zola's prose (coupled with his thematic interest in patterns of repetition and recurrence) that the prose-as-music metaphor aims to explain in this case. Music, after all, is an art form in which recurrence and repetition are fundamental elements of composition.

Yet there is a good deal more going on in the specifically Wagnerian comparison of the 1890s than the conventional prose-as-music metaphor might suggest. For a start, Zola's

\footnotetext{
${ }^{40}$ Paul Ginisty, review of La Bête humaine, Gil blas, 15 March 1890, p. 3; France, 'L'Argent', p. 2.

${ }^{41}$ Henry Céard, 'M. Zola à l'opéra', Le Matin, 13 October 1894, p. 1.

${ }^{42}$ See for instance Calvin S. Brown, 'Music in Zola's Fiction, Especially Wagner's Music', PMLA, 71 (1956), 84-96; Auguste Dezalay, L'Opéra des Rougon-Macquart: essai de rythmologie romanesque (Paris: Klincksieck, 1983); Lethbridge, 'Introduction', pp. 8-9; and Jean-Louis Cabanès, 'Travail: roman lyrique', in Lire / dé-lire Zola, pp. 327-47.
} 
comments to Le Journal are, to say the least, conflicted. If as we have just seen the ZolaWagner association had been around since at least 1890, Zola's embrace of it here is deliberately paradoxical and provocative. Though Wagner is the darling of the SymbolistDecadent avant-garde, beloved of a small, elite public of Princesse de Guermantes-like aficionados, the true equivalent of Wagner in fictional prose is . . Zola! - and it always has been. Indeed, this claim serves to set up the even more gleeful paradox that follows, as Zola pronounces: 'Symboliste! Je crois bien que je le suis. ${ }^{, 43}$ The Symbolists do not, contrary to popular belief, hold a monopoly on aesthetic ambition and formal innovation, still less on (small-'s') symbolism itself; once again, Zola got there first. In other words, the Wagner reference allows Zola to make a grab for some of the symbolic capital typically accruing to canonized, avant-garde writers in an opposite and rival corner of the literary field. ${ }^{44}$ And yet in this very same quotation, Zola's old instincts prevent him fully committing to this formalist claim. Hence the 'composedness' of his novels is apparently not 'dans une vue de beauté', but reflects his urge to 'faire vivant', an ambition that is then rather implausibly attributed to Wagner as well: Zola's repetitions and Wagner's leitmotifs are allegedly the result of their shared 'sentiment de la vie' and are thus presented as philosophically motivated. As applied to his own work, at least, this claim is not ridiculous; Zola is evoking his interest in the dialectic of reproduction and evolution in the natural world, which would be metaphorized in the leitmotif's recurrence and development. But this way of putting things seems disingenuous in the context, where what is at stake is fairly clearly the old charge that the Naturalist formule systematically slighted the aesthetic dimension of literature. More honest - though also more testy_-is Zola's letter to a certain 'M. Bonnet', written later that same year:

Ce que vous nommez des répétitions se trouve dans tous mes livres. C'est en effet un procédé littéraire, employé d'abord timidement, puis que j'ai peut-être poussé à l'excès. Cela, selon moi, donne plus de corps à l'œuvre, en resserre l'unité. Il y a là quelque chose de semblable aux motifs conducteurs de Wagner. ${ }^{45}$

This time, the analogy between Zolian 'key-passage' and Wagnerian letimotif is straightforwardly a formal one: both are phrases that recur in recognizable form, with some

\footnotetext{
${ }^{43}$ Zola, Écrits, p. 316.

44 See Bourdieu, p. 205.

45 Émile Zola, Correspondance, ed. by B.H. Bakker, 10 vols (Montréal: Presses de 1'Université de Montréal, 1978-95), VIII (1991), 171-72; letter of 24 October 1894.
} 
degree of development, whose motivation is endogenous to the work qua aesthetic object, and which tend towards the eminently aestheticist end of 'unity'. 46

We might assume that others who drew the same analogy did so for similar reasons. Ginisty certainly does; France acknowledges that the comparison is possible. The most interesting case is Céard's. To be sure, Céard states the case almost exactly as Zola himself might have wished, including with the revisionist note of Zola's interview with Le Journal (that is, the insistence that Zola's work has always been Wagnerian). Céard also neatly rebuts those perennial accusations of negligence and 'unconsciousness', and it would be easy to see in this intervention merely a supportive article by a friend and colleague. Yet if Céard begins with the merely second-hand observation that 'on annonce sans démentis que M. Émile Zola écrit un livret', this is because he was in October 1894 no longer part of the older man's circle. The two had ceased to frequent each other a year earlier, following Céard's hostile reaction to the operatic adaptation of L'Attaque du moulin, also set by Bruneau and staged at the OpéraComique in November $1893 .{ }^{47}$ To grasp what was at stake in his hostility, we must read closely the final paragraph of the 1894 article:

Et puis [...] qui sait si l'Opéra recherché aujourd'hui par M. Zola n'est pas une sanction définitive pour un artiste et pour une œuvre. C'est là précisément où, grâce aux chanteurs, la parole antique s'accomplit et la gloire vole réellement sur la bouche des hommes, et peut-être les orgues de Barbarie portés sur les dos d'Auvergnats sont-ils le meilleur véhicule vers l'immortalité.

Rigoletto est certainement plus connu que le Roi s'amuse. ${ }^{48}$

There are a number of barbs here. The rhetorical question ('qui sait') plainly undermines the notion that operatic collaborations can somehow consecrate an author definitively. On the contrary, the bathetic contrast between the classicizing 'parole antique', on the one hand, and the image of the provincial organ-grinder, on the other, hints that Zola's musical projects are as likely to belong in the village square as on Mount Parnassus. And the last twist of the knife comes in the reference to Rigoletto. Whether or not Céard means this as a snide swipe at Zola's Italian antecedents, the allusion to Giuseppe Verdi's 1851 opera is not entirely flattering. Rigoletto is not better than the Victor Hugo play that it has utterly eclipsed; it is merely better known, 'plus connu', which is to say, it is popular. Steven Huebner confirms the piece's 'proven

\footnotetext{
${ }^{46}$ For more on Zola, Bruneau, and the Wagnerian influence, see Steven Huebner, French Opera at the Fin de Siècle: Wagnerism, Nationalism, and Style (Oxford: Oxford University Press, 1999), ch. 24.

${ }^{47}$ On this episode, see Henri Mitterand, Zola, tome III: L'honneur, 1893-1902 (Paris: Fayard, 2002), pp. 65-71.

${ }^{48}$ Céard, 'M. Zola à l'opéra', p. 1.
} 
track record' as a crowd-pleasing staple at the Opéra-Comique in the late 1880s and early 1890s. ${ }^{49}$ Its success no doubt had something to do with the fact that it contains one of the most recognizable tunes in western musical history_-'La donna è mobile', which was already in 1894 as much a staple of street organists as of the operatic stage. That 'widespread approval' among a middle-class public, and broader social dissemination beyond the opera house, contrasts sharply with the edgier, avant-garde, controversial status of Wagner, that Zola had sought to appropriate in these years. ${ }^{50}$

Céard's conclusion thus cunningly undermines whatever favours the article appeared to do for Zola, overwriting the high-brow Wagnerian comparison with the more middle-brow allusion to Verdi. More specifically, through the reference to the organ-grinder, Céard proposes a less exalted way of understanding Zola's repetitions: not as aesthetic experimentation, but as catchy 'hooks' designed to appeal to a wide public. ${ }^{51}$ No doubt this move expresses Céard's resentment at the ever-wider stride of the Zolian colossus; certainly, this is how Mitterand understands the end of their friendship. ${ }^{52}$ But the suggestion is surely not implausible - and may indeed strike us as rather more plausible than the Wagner analogy. Certainly, the evaluatively-minded might point out that while Wagner's leitmotifs constantly evolve, Zola's key-passages turn on near-exact repetition, and therefore represent a less ambitious aesthetic device. 'Il ne se renouvelle pas, [...] et n'évolue guère', complained Bloy, in bemoaning Zola's 'inusables clichés'. ${ }^{53}$ But this is not the course I propose to take. In the final section, I want to consider what Zola's repetitions, understood just as Céard snidely encourages us to, can teach us about the question of the 'popular' in art in fin-de-siècle France.

\section{Repetition as mnemonic}

Six months after likening his use of repetition to Wagner's leitmotifs, in February 1895, Zola returned to the question in an article for Le Figaro where he offered a rather different explanation of the technique:

\footnotetext{
${ }^{49}$ Huebner, French Opera, p. 3.

${ }^{50}$ David Charlton, 'The Nineteenth Century: France', in The Oxford Illustrated History of Opera, ed. by Roger Parker (Oxford: Oxford University Press, 1994), pp. 122-68 (p. 163).

${ }^{51}$ Indeed, William Ashbrook notes that Rigoletto contains 'some simple use of reminiscence motives'; 'The Nineteenth Century: Italy’, in The Oxford Illustrated History of Opera, pp. 169-205 (p. 192).

${ }^{52}$ Mitterand, Zola, tome III, pp. 68-70.

${ }^{53}$ Bloy, Je m'accuse, p. 19.
} 
Ah! la clarté, la limpidité, la simplicité! imaginez-vous que j'en meurs! [....] Si mes livres sont si longs, si je me répète tant, c'est que je crains toujours de n'avoir pas été compris. ${ }^{54}$

Call this the 'pedagogical hypothesis': Zola repeats himself in order to make sure his central ideas are understood. On this showing, repetition is not really a question of style at all, but rather a utilitarian strategy. Certainly there is nothing shocking about this claim at a moment when Zola was already embarked upon the first of his two series of thesis novels, Les Trois Villes. As Laville points out, the didactic purpose of these later novels is clearly served by the reduction of some of their key 'thèses défendues' to 'des énoncés stables quelle que soit la voix énonciative qui les profère'. ${ }^{55}$ Again, however, Zola does not appear to be speaking only proleptically here, but also retrospectively; these words, it seems, are supposed to describe his entire oeuvre. But can Les Rougon-Macquart really be called didactic or pedagogic? At the very least, certain of the novels have been called those things. France, in his review of L'Argent, praises it for being 'didactique, encyclopédique' in its representation of the milieu of high finance; while the year before, in a very mixed review of La Bête humaine presented in dialogue form, the same critic had noted with heavy sarcasm the novelist's 'soins pédagogiques', his 'ruses maternelles pour apprendre aux jeunes gens à distinguer la machine d'express [...] de la petite machine-tender' ${ }^{56}$ Intriguingly, the same impression strikes the same critic as a defect or a quality in works by the same author published only a year apart. This ambivalence might be partly explained by Philippe Hamon's observation that 'le projet réaliste s'identifie avec le désir pédagogique de transmettre une information' which encourages both 'une hypertrophie de la redondance' and 'une hypertrophie des procédés anaphoriques' ${ }^{57}$ That is, the realist text is in some fundamental way pedagogical, but the closer the text comes to assuming this impulse fully, the more it descends to the level of mere Barthesian lisibilité, reducing its reader to the status of passive, infantilized receiver of 'information'. As Hamon shows, this accounts for some of the repetitive features of realist narration, including Zola's - though what he emphasizes in this connection are repetitive narrative structures, for instance, scenes in which one initiated character explains to another naive character some sort of technical or specialized

\footnotetext{
${ }^{54}$ Émile Zola, 'A la jeunesse', in Euvres complètes, ed. by Henri Mitterand, 21 vols (Paris: Nouveau Monde, 2002-09), XVII, 388-91 (p. 389). References to this edition are given in the text, preceded by the abbreviation $O C$.

${ }^{55}$ Laville, 'Les Évangiles', p. 322.

${ }^{56}$ France, 'L'Argent', p. 2; Anatole France, 'Dialogues des vivants: La Bête humaine', Le Temps, 9 March 1890, p. 2.

${ }^{57}$ Philippe Hamon, 'Un discours contraint', in Roland Barthes, Leo Bersani, Philippe Hamon, Michael Riffaterre, and Ian Watt, Littérature et réalité (Paris: Seuil, 1982), pp. 119—81 (p. 134).
} 
knowledge. These are the unmistakeable scenes in Zola in which the formula 'il lui expliqua' or 'il lui nomma' precedes some exhaustive enumeration of details, which is precisely the kind of thing France has in mind, I think, when he speaks of the works as 'didactique, encyclopédique'. ${ }^{58}$

And yet this does not seem to account very well for the sort of stylistic repetition with which we began. If the 1895 article has any light to shed on this type of repetition, it is not in its notion of didacticism, but in the idea of 'simplicity': 'Ah! la clarté, la limpidité, la simplicité! imaginez-vous que j'en meurs!'. 'Simplicity' too is a word that seems particularly apt to describe Zola's later writing, but which turns out to have its critical antecedents during the Rougon-Macquart era. In the review of La Bête humaine from which I have already quoted, Jules Lemaître mingled his criticism of Zola's glaring procédés with some praise: 'La Bête humaine est un des romans où $\mathrm{M}$. Zola a su le plus puissamment exprimer sa vision simplifiée et si triste des hommes et des choses,' he wrote, while one of the more favourable characters in France's dialogical review of the same novel refers to Zola's 'génie, grand et simple'. ${ }^{59}$ Both are speaking thematically, we assume; contrastingly, France gives this word a negative valence in stylistic terms, as when he describes the style of L'Argent as 'simple, [...] épaissi et négligé' ${ }^{60}$ Au contraire, replies the Zola of 1895: that simple style, far from being the result of neglect, is obtained through an almost Flaubertian process of self-torture ('Ah! [...] imaginezvous que j'en meurs!'), at the conclusion of which the perfectionist novelist must grimly accept that the work will never be simple enough, long enough, repetitive enough.

The question still remains: why? To answer it, let us return to the key-passage from $L a$ Bête humaine. Jacques Lantier, we remember, feels:

une soif toujours renaissante de venger des offenses très anciennes, dont il aurait perdu l'exacte mémoire. Cela venait-il donc de si loin, du mal que les femmes avaient fait à sa race, de la rancune amassée de mâle en mâle, depuis la première tromperie au fond des cavernes? (RM IV: 1044)

I have suggested that the pedagogical hypothesis, or Laville's notion of the didactic repetition of certain 'thèses défendues', cannot account for this passage very well. I should explain what I mean. To be sure, one of the characters in France's review, complaining that Jacques's selfanalysis is implausible, comments:

\footnotetext{
${ }^{58}$ See Hamon, 'Un discours contraint', p. 148, for examples.

${ }^{59}$ Lemaître, 'La Bête humaine', p. 1; France, 'Dialogues des vivants', p. 2.

${ }^{60}$ France, 'L'Argent,', p. 2.
} 
Il se demande si ses désirs monstrueux ne viennent pas 'du mal que les femmes ont fait à sa race, de la rancune amassée de mâle en mâle, depuis la première tromperie au fond des cavernes'. Il semble qu'il ait étudié l'anthropologie préhistorique, lu Darwin et suivi les derniers congrès des criminalistes. On voit trop que M. Zola a pensé pour lui. $^{61}$

The question of whether it is plausible that Jacques's inner monologue should be so articulate (which is also the question of whether this sort of free indirect discourse is an inner monologue at all) is a potentially interesting one, though not one that falls within the scope of this article. France's other point, however, is simply wrong. The claim that Jacques seems to have read Darwin suggests nothing so much as that Anatole France has never done so himself, for nothing in this key-passage is remotely Darwinian; nor is it obviously criminological, at least not in any technical way. And while it evokes an image of prehistory, it seems doubtful that an uninformed reader would learn something about early humans from this passage, or would be able to summarize its burden for another person in the form of a 'thesis' that might be said to belong to the domain of anthropology.

This is not to say that the thrice-repeated key-passage in La Bête humaine does not entertain a relationship with these discourses, including with a certain ambient misconception of Darwin's work. But that relationship is one of simplification, and what it produces is less a 'thesis' than, as Céard puts it, an 'idée dominante', even an idée fixe. The passage is in a sense a reworking of a key phrase that recurs not only in Zola's ébauche and his chapter plans, but also in letters to Jacques van Santen Kollf, with whom the author shared the genesis of his latest novel throughout $1889 .{ }^{62}$ That phrase is 'l'homme des cavernes', which Zola uses to connote the idea - drawn from a muddle of Darwin and Lombroso- that primitive tendencies can recur in civilized humans, a thesis encapsulated in one of the many rejected titles for the novel: Retour atavique. Yet 'l'homme des cavernes', having presented itself repeatedly to Zola during the planning stages, disappears entirely in the manuscript — where it is, we might say, replaced by the fully formed repetition already quoted, all three occurrences of which appear without emendation. Even then, the 'idée dominante' has not completed its journey. As we have seen, France's review of 9 March quotes the idea almost in full. The day before, Lemaittre too had noted this moment with apparent approval, paraphrasing-yet, crucially, doing so in the novel's own unmistakeable vocabulary - to the effect that: 'Quant à Jacques Lantier, ce

\footnotetext{
${ }^{61}$ France, 'Dialogues des vivants', p. 2.

${ }^{62}$ Zola, Correspondance, VI (1987), 395; letter of 6 June 1889.
} 
n'est pas lui qui veut ni qui agit, c'est la longue série des mâles ses ancêtres trahis par la femelle dès l'âge des cavernes. ${ }^{63}$ Nor has the phrase run its course at that moment; five days later, in an interview in Le Gaulois, Zola would remark upon Lemaître's positive take on La Bête humaine:

Lemaître m'a causé une bien grande joie avec son article du Figaro. Il a expliqué $L a$ Bête humaine, il l'a commentée mieux que je n'aurais su le faire: Il a montré mon Lantier ce qu'il est, [...] un malheureux, victime de prédestinations ataviques, qui malgré lui et bien qu'il en souffre, venge sur les femmes qu'il rencontre la première tromperie au fond des cavernes. ${ }^{64}$

If this phrase is not exactly the didactic ramming home of a 'thesis' envisaged by Zola in his 1895 discussion of repetition, then, it nevertheless has something of the mnemonic effect that pedagogical repetition is presumably supposed to have. It is, like Rigoletto's third-act showstopper, catchy, a kind of conceptual earworm, and one that has evidently wormed its way into the ears of both France and Lemaître, who cite it - the one approvingly, the other critically, which actually makes no difference - in such a way as to propagate it beyond the novel itself. Zola cannily helps the process along with some innocent self-citation in a publicity shot the following week.

What I would like to suggest, then, is that these mnemonic repetitions have everything to do with Zola's canny understanding of the literary marketplace and, especially, of the rhythms of serial publishing and reading. The key-passage of La Bête humaine appears at the beginning, middle and end (chapters 2, 6, and 11 of 12) of a novel serialized over three and a half months, from November 1889 to March 1890. The example ridiculed by Bloy, ostensibly from Lourdes, is even more telling. 'L'abbé Pierre est un de ces prêtres [...] "qui fait chastement, honnêtement son métier" [...]. Il faut croire que notre poète juge cette idée aussi forte qu'éblouissante, car je l'ai lue-identiquement exprimée,-jusqu'à cinq fois, pages 34, $273,274,319$, et 597. ${ }^{65}$ As a critique of Lourdes, this is dishonest, since the page numbers refer to every time Pierre Froment's vocation is referred to as a 'métier'-hardly a stylistic scandal. But what Bloy is probably referring to is the fact that the passage from near the end of Lourdes in which Pierre is described as a

\footnotetext{
${ }^{63}$ Lemaître, 'La Bête humaine', p. 1.

${ }^{64}$ Émile Zola, quoted in Edmond Le Roy, 'Autour de La Bête humaine: chez Émile Zola', Le Gaulois, 13 March 1890 , pp. 1-2 (p. 2).

${ }^{65}$ Bloy, Je m'accuse, p. 38.
} 
prêtre sans croyance veillant sur la croyance des autres, faisant chastement, honnêtement son métier, dans la tristesse hautaine de n'avoir pu renoncer à sa raison, comme il avait renoncé à sa chair (OC, XVI: 339)

appears in the final chapter of the next novel in the Trois Villes series, Rome, where Pierre is described as a:

prêtre sans croyance veillant sur la croyance des autres, faisant chastement, honnêtement son métier, dans la tristesse hautaine de n'avoir pu renoncer à son intelligence, comme il avait renoncé à sa chair d'amoureux. (OC, XVI : 755)

Later, in the first chapter of the final instalment of the cycle, Paris, we hear that Pierre is a: prêtre sans croyance veillant sur la croyance des autres, faisant chastement, honnêtement son métier, dans la tristesse hautaine de n'avoir pu renoncer à son intelligence, comme il avait renoncé à sa chair d'amoureux. (OC, XVII: 25-26)

The idea is then repeated twice more in the same novel; this first time in book 2, where Pierre is described as a 'prêtre incroyant veillant sur la croyance des autres, faisant chastement, honnêtement son métier, dans la tristesse hautaine de son mensonge' (OC, XVII: 139); then again in book 5 , where he is a 'prêtre incroyant, qui continue, honnêtement, chastement, à veiller sur la croyance des autres' (OC, XVII: 323). Surely Bloy is right to find this sort of repetition outrageous?

But consider that the first of these examples originally appeared in Gil Blas on 15 August 1894; the second, from Rome, in Le Journal on 7 May 1896; and the last three, from Paris, also in Le Journal on 23 October 1897, 30 November 1897, and 6 February 1898. The rhythm of this latter trio closely reflects that of the 'première tromperie' passage from La Bête humaine, which originally appeared in La Vie populaire on 24 November 1889, 29 December 1889, and 20 February 1890 . With this kind of periodicity, and in a format where 'flipping back' is not impossible but surely not the norm, repetition conceivably has more the effect of an echo, a distant recollection. It can thus function as both a leitmotivic unifying device and a mnemonic tactic; it is, in short, a stylistic feature perfectly adapted to both cyclical structures and serial publication, and to a literary mass market in which serialization is the norm. If this claim seems obvious, it is worth remembering that press publication was still axiomatically viewed as inimical to artistic purity in the final decades of the nineteenth century, while the literary genre most closely associated with this form of dissemination, the roman-feuilleton, occupied the lowest rung on the fin-de-siècle hierarchy of genres and was a by-word for the 
cynical exploitation of vulgar tastes. ${ }^{66}$ Zola himself, moreover, often appears to have shared these prejudices. Tim Farrant notes for instance that the author's literary criticism of the late 1860s and early 1870s frequently lamented the fragmentary impact of feuilleton publication on the novel as a form. ${ }^{67}$ And when in 'J'Accuse...!' Zola wishes to denounce the more outlandish fabrications of the military hierarchy, the phrase he reaches for is 'roman-feuilleton' (OC, XVIII: 438, 441). Most tellingly of all, however, the question of feuilleton publication arose in the same interview with Le Gaulois in which Zola cited the 'première tromperie' idea. The paper's rather smug reporter needles Zola about his success-meaning financial successand his gargantuan readership, in anticipation of the first run of La Bête humaine, which would see Zola shift his millionth volume. Zola, sensing a trap, neither disavows that success nor glories in it, though he does acknowledge that it has damaged his standing with his confrères and with critics. Why publish in feuilleton form at all then, asks Le Roy? 'Je ne suis pas riche,' Zola replies, 'et les vingt mille francs qui me sont offerts par les journaux qui prennent ainsi mes romans me sont souvent utiles. ${ }^{68}$

This response, given against the background of a career-long commitment to prepublication in the press even as a wealthy and established novelist, can only strike us as deceptively glib. It seems clear that, on the contrary, publication in the popular press was utterly central to Zola's conception of the place of fiction in his contemporary society. As we saw in starting, Jameson positions Zola as perhaps the last writer of serious aesthetic intention to be genuinely popular, 'the last coexistence of the art novel and the best-seller within a single text' ${ }^{69}$ But as Jameson has explained more recently, these two dimensions are not merely coexistent, but consubstantial:

Everything that is admirable and productive in Zola [...] can also be judged as a shameless manipulation of poetic perception that has been harnessed to a commercial project and that scarcely merits the 'distinction' of the literary in the first place (whence Zola's endemic exclusion from the canon). ${ }^{70}$

This is what is happening when, for instance, Max Nordau fulminates that Zola's notion of the 'experimental novel' - otherwise so patently absurd!- - must be 'a conscious premeditated snare', akin to the fancifully futuristic-sounding names that unscrupulous salesmen like to give

\footnotetext{
${ }^{66}$ See Bourdieu, Les Règles de l'art, pp. 56, 205, 207; and Diana Holmes and David Looseley, Imagining the Popular in Contemporary French Culture (Manchester: Manchester University Press, 2013), pp. 95-98.

${ }^{67}$ See Tim Farrant, 'Fragmentation, feuilleton, Form: Balzac, Baudelaire, Zola', in Dix-Neuf, 21 (2017), 245-57 (pp. 253-54).

${ }^{68}$ Le Roy, 'Autour de La Bête humaine', p. 2.

69 Jameson, Postmodernism, p. 63.

${ }^{70}$ Fredric Jameson, The Antinomies of Realism (London: Verso, 2015; first pub. 2013), p. 46.
} 
their wares (“"Electric" braces or "Magnetic" ink' are Nordau's examples). ${ }^{71}$ But shorn of its tone of histrionic hostility, this is not a bad interpretation-unusually, indeed, it credits Zola with a conscious artistic choice, albeit a cynical one. Indeed, if we could only unburden ourselves of the notion that the desire to sell copies - that is, to be read, to be popular-is somehow cynical, we might even see this as among the best interpretations of the idea of the roman expérimental. And this is, finally, what I am trying to suggest about the relationship between Zola's use of catchy repetition and feuilleton (or cyclical) publication: here is a stylistic device that encapsulates Zola's aspiration not only to be read, but to be readable.

\section{Conclusion}

By 1900, it was an established principle that 'popular art' was a contradiction in terms. ${ }^{72}$ The intricate craft of the true artist and the mass market are inimical, the story went, and still goes; as Bloy observed of Flaubert, 'ses livres, à si grand'peine obtenus, se vendirent peu, n'étant pas faits pour la multitude. ${ }^{73}$ Lamenting his late mentor's death in a chronicle of 1881 , Maupassant similarly complained that the master's final novel, Bouvard et Pécuchet, was doomed to be a failure: 'Les critiques vont [...], au nom de l'art pour tous, attaquer cet art à l'usage des seules intelligences. ${ }^{74}$ A strange fear, given that the critics of the day were more prone to pour scorn on writers like Zola, whose mass success seemed to exclude them from the domain of art. In introducing his ambivalent eulogy to Zola in 1903, Henry James noted that his contemporary age was characterized by a massive production of literary fiction that was in inverse proportion to the quality of its fabrication. 'As to why people should like anything so loose and mean as the preponderant mass of the "output," so little indebted for the magic of its action to any mystery in the making, is more than the actual state of our perceptions enables us to say,' he sniffed. ${ }^{75}$ This is a sneaky opening, for while the piece goes on to say that Zola's work rises, at least in parts, above the mass of fin-de-siècle literary 'output', one doubts James would have begun a tribute to any other novelist in quite these terms. The point is to evoke, even while apparently refuting, the lingering suspicion that Zola's was a churned-out art, with

\footnotetext{
${ }^{71}$ Max Nordau, Degeneration, ed. by George L. Mosse (Lincoln: University of Nebraska Press, 1993), p. 490.

${ }^{72}$ See Bourdieu, Les Règles de l'art, e.g. pp. 156, 195, 204; and Holmes and Loosely, Imagining the Popular, p. 96.

${ }^{73}$ Bloy, Je m'accuse, p. 21.

${ }^{74}$ Guy de Maupassant, 'Bouvard et Pécuchet', Supplément du Gaulois, 6 April 1881; in Chroniques, ed. by Gérard Delaisement, 2 vols (Paris: Rive Droite, 2003), I, 183-6 (p. 184).

${ }^{75}$ James, ‘'́mile Zola’, p. 871.
} 
little 'mystery in the making' - a suspicion whose best evidence, as always, came from the fact that Zola was so damnably popular. ${ }^{76}$

For his part, Zola often made clear his rejection of this anti-democratic aesthetic attitude: in 'L'Argent dans la littérature' (1880), for instance, he refuted the notion that financial success invalidates literary merit, while in 'Le Solitaire' (1896) he rebutted the converse notion that poverty, obscurity and incomprehension were the natural state of the literary genius. His aspiration to readability put these ideological positions into textual practice, but at a cost. For lurking behind 'readability' is, once again, Barthes's dreaded lisibilité, and as Claire White has shown, Zola has become for a certain critical tradition the paradigmatic case of that disparaged mode of intelligibility, which falls so obstinately below the level of avantgarde jouissance. ${ }^{77}$ Against such accounts of an aesthetically uninteresting Zola, a number of critics, most notably Susan Harrow, have insisted on Zola's right to be considered a 'protomodernist', an 'avant-avant-garde experimentalist' engaged in a serious recherche d'art (to borrow Maupassant's phrase). ${ }^{78}$ This re-evaluation of Zola has been crucial in revivifying Zola studies. Yet what I have attempted to show in this article is that the 'readable' and the 'innovative' are not necessarily opposed — that a recherche d'art need not be recherché. Taking Zola's aesthetic and stylistic innovations seriously must involve taking seriously those features of his work that are modern, but not modernist. Conversely, while studies of the 'popular' in literature tend quite reasonably to focus on questions of exciting narrative and plotting (exactly what is at stake, one supposes, in Zola's disparaging use of the term roman-feuilleton in 'J'Accuse ... !'), and assume in Diana Holmes's words that popular fiction 'invit[es] a reading that registers but does not examine the words themselves', I have been suggesting that through his use of repetition, Zola was pursuing a democratic, accessible literary formule on a stylistic level, even before his explicitly political later period. ${ }^{79}$ For critics raised in the FlaubertianJamesian-Barthesian aesthetic tradition - that is, most of us - this device can seem hard to swallow. Yet when understood as part of the conscious pursuit of readability, it becomes, on the contrary, strikingly novel.

\footnotetext{
${ }^{76}$ Bourdieu suggests that Zola's reputation was only saved from this stigma by his self-reinvention as an 'intellectual' during the Dreyfus Affair; see Les Règles de l'art, p. 215.

${ }^{77}$ See Claire White, 'Easy Reading: Zola's Kitsch', in Lucidity: Essays in Honour of Alison Finch, ed. by Ian James and Emma Wilson (Oxford: Legenda, 2016), pp. 72-85 (pp. 75-77).

${ }^{78}$ Susan Harrow, Zola, The Body Modern: Pressures and Prospects of Representation (Oxford: Legenda, 2010), p. 1.

${ }^{79}$ Holmes and Looseley, Imagining the Popular, p. 93.
} 